Review

\title{
CLIMATE CHANGE IMPACT ON MOUNTAIN BIODIVERSITY: A SPECIAL REFERENCE TO GILGIT-BALTISTAN OF PAKISTAN
}

\author{
S. Ishaq'*, M. Z. Khan', F. Begum', K. Hussain', R. Amir', A. Hussain', S. Ali' \\ 1. Department of Environmental Sciences, Karakoram International University, Gilgit-Baltistan, Pakistan \\ 2. Forest, Wildlife and Environment Department of Gilgit-Baltistan \\ 3. Pakistan Institute of development economics Islam Abad
}

\section{ABSTRACT}

Climate Change is not a stationary phenomenon; it moves from time to time, it represents a major threat to mountainous biodiversity and to ecosystem integrity. The present study is an attempt to identify the current knowledge gap and the effects of climate change on mountainous biodiversity, a special reference to the Gilgit-Baltistan is briefly reviewed. Measuring the impact of climate change on mountain biodiversity is quite challenging, because climate change interacts with every phenomenon of ecosystem. The scale of this change is so large and very adverse so strongly connected to ecosystem services, and all communities who use natural resources. This study aims to provide the evidences on the basis of previous literature, in particular context to mountain biodiversity of Gilgit-Baltistan (GB). Mountains of Gilgit-Baltistan have most fragile ecosystem and are more vulnerable to climate change. These mountains host variety of wild fauna and flora, with many endangered species of the world. There are still many gaps in our knowledge of literature we studied because very little research has been conducted in Gilgit-Baltistan about climate change particular to biodiversity. Recommendations are made for increased research efforts in future this including jointly monitoring programs, climate change models and ecological research. Understanding the impact of climate change particular to biodiversity of GB is very important for sustainable management of these natural resources. The Government organizations, NGOs and the research agencies must fill the knowledge gap, so that it will help them for policy making, which will be based on scientific findings and research based.

KEYWORDS: Mountainous biodiversity, Ecosystem services, Sustainable management, Wild Fauna

*Corresponding Author: (Email: Sultan.iq1 $1 @$ gmail.com)

\section{INTRODUCTION}

Climate is not a stationary phenomenon it varies from time to time. It is a product of weather which always experiences variations over space and time [1]. Climate change is resulting from a growing concentration of Greenhouse Gases (GHGs) and uses of fossil fuels and other anthropogenic activities has become a major worldwide concern [2]. Anthropogenic emissions of GHS such as carbon dioxide $\left(\mathrm{CO}_{2}\right)$, methane $\left(\mathrm{CH}_{4}\right)$, and nitrous oxide
$\left(\mathrm{N}_{2} \mathrm{O}\right)$ have led to increases in their atmospheric concentration and cause warming of the lower atmosphere [3]. Human induced climate change threatens ecosystems and human health on global scale. Climate change has greatest impact on those countries that are already poor due to lack of resources and access to scientific information. Earth's average surface temperature rises are likely to surpass the safe threshold of $2^{\circ} \mathrm{C}$ [4]. The average temperature of today's world has already increased by $0.6^{\circ} \mathrm{C}$ from the middle of the 1800 s. 
The instrumental records from the past years have shown an increase in mean temperature all over the globe [4], with the global mean temperature increase at the rate of $0.007 \circ \mathrm{C}$ decade - ${ }^{-}$over the last century [5]. The overall global mean sea level rose by $19 \mathrm{~cm}$ from 1901 2010 [6]. At present climate is changing rapidly, the atmosphere has responded to the increased inflows of $\mathrm{CO}_{2}$ and other GHGs through worldwide $[7,8]$.

The land use change brings number of changing in climatic pattern. Excessive deforestation leads to decrease in precipitation level and increase in surface temperature on global scale, thus it change whole global climatic model [9]. The scale of this change is so large and very adverse so strongly connected to ecosystem services, and all communities who use natural resources. Biodiversity change is now considered an important global change [10]. Since first "Intergovernmental Panel on Climate Change" (IPCC) it has been observed that earth global temperature has been increasing because of climate change, which is more dangerous for over all biodiversity. The altitudinal distribution of vegetation is expected to shift to higher elevation and some species with climatic ranges limited to mountain tops possibly will become extinct because of disappearance of their habitat or reduced migration potential [11]. Mountain Region are Considered as sensitive ecosystem. Climate Change represents major threats to the ecosystems integrity and global biodiversity. The consequences of these climatic changes have negative impact on number of wildlife and other natural ecosystems [12]. Mountains have most fragile ecosystem in the world [13]. Change in the global temperature and local precipitation might significantly change the altitudinal ranges of some keystone species existing in the different ranges of mountainous areas, and create more stresses on the fragile ecosystem of mountainous areas [14, 15]. According to Nogues-Bravo et al. [16], it is difficult to estimate the exact effect of climate change on mountainous areas because of the doubts associated with the climatic scenario and also the presence of nonlinear feedback and the knowledge gap between the impacts. Many Studies show that the mountain ecosystems are more vulnerable to climate change $[17,18,19]$. According to Theurillat and Guisan, 2001, indicated that climate change in mountainous ecosystem are most noticeable in the areas such as at Boundary Ecosystems ("Ecocline") or at Eco tones, where two ecosystems are meet. Species can response either by migrating or though adaptation [20].

\section{CLIMATE CHANGE IN PAKISTAN}

South Asia is considered as one of the most susceptible regions for global climatic changing. In Pakistan there has not been such extensive research carried out regarding climate change and biodiversity as compared to other parts of the world. As Pakistan is an agricultural based country, the country depends on the Indus irrigation system, as Indus River is one of the key water carriers of South Asia rising from the Tibetan Plateau and the Himalayas [21]. The country is highly vulnerable to climate change, hence large floods, drought and biodiversity loss is expected in future [1]. According to a survey conducted by Khan et al. [2] about $40 \%$ of Pakistani's believe that climate is changing moderately while $60 \%$ of them believe that it has been changing harshly. Many studies indicate that change in climate affecting, directly or indirectly the whole biodiversity and their habitats [22, 23, 24] 
leading to their displacement and in most harsh cases, even extinction. Change in climate also affecting the competitiveness of many species by changing growth, death rates and regeneration success rates [25]. However a vital problem in mountain ecosystem concern to climate change is the increased in the erosion and in reduction of the slope stability [14]. It is being found that change in climate has caused a shift in habitat from wet monsoon forest to savannah [26]. Many unique species of flora and fauna are also on the edge of extinction due changing in habitat conditions. Increase in high temperature and precipitation patterns can has also increase forest insects, pest and weeds which result in greater damage of forest vegetation, change the species composition and reduce the area of forest [26]. Globally the natural ecosystem has been affected by current climate change. Slatyer [27] stated that, the Australian natural ecosystem is more vulnerable to climate change, the particular impact will depends on the adaptation and resilience of individual species. Due to increase in warming at alpine areas $[13,18,27,28]$ the species which are already occupying the high altitudes areas have less possibility for up moving migration $[29,30]$. Most of the species in particular ecosystem cannot adapt to the sudden climate change, in the cause forest, the species with very limited ranges, which have nowhere to migrate are more vulnerable to climate change. And the probability of species to higher altitudes to find the similar condition of those at present will certainly be limited by some other factors like water availability and soil type and many other external factors [31]. As from literature it is found that Pakistan in more vulnerable to climate change in coming decades. Most of the areas in Pakistan are showing positive trend in temperature for the period 2011-2050 and maximum rise is expected in Gilgit-Baltistan, Central and Southern Punjab and lower KPK [32]. This Increase in rate of temperatures will increase the heat waves which have likely to be adverse effect on biodiversity and water resources in Pakistan [33]. As Pakistan is agriculture dependent country; change in climate is expected to decrease the crop production that would have a great effect on the livelihood of Pakistan [34].

\section{CLIMATE CHANGE IMPACT ON MOUNTAIN BIODIVERSITY}

Mountainous ecosystems are Fragile [35] and more susceptible to climate change [36, 37]. Most of the global biological diversity hotspots are located in mountainous and coastal regions. Mountains are the most fragile environment on earth, and one of the major "experimental fields of nature" because of steep environmental slope, wilderness and habitat types, and rich for biodiversity and water and they also provide services with tangible economic value $[16,38]$.

Mountain ecosystems cover about one-fifth of the earth's continental areas [18] and so called storehouses of global biodiversity [39] these area host many threatened and endemic species of world so climate change is considered to be big threat to mountain biodiversity, because they are likely to be more exposed to extreme events of weather [40].

The hotspots of Himalayas, Karakorum and Hindu Kush (HKH) have a rich of species, gene pools and ecosystems which have global importance. Human-induced climate change is predictable threat to species of Himalayas. These mountain environments are strongly 
affected by climate, due to their vertical (altitudinal) dimension [41, 42].

Environmental change is by now beginning in the high-altitude areas where glaciers are abundant. Accelerated glacier melting is only one of the continuing changes in regions of $\mathrm{HKH}$, which faces many different pressures, among them the impacts of climate change [43]. Nogue's-Bravo et al. [16] have provided an assessment on surface temperature changes in mountainous area of the world. They projected that the average temperature change varied between "+3.2 1C (+0.4 1C/per decade) and +2.1 1C (+0.26 1C/per decade) for 2055 and $+5.31 \mathrm{C}(+0.481 \mathrm{C} /$ per decade) and +2.8 1C for 2085 (+0.25 1C/per decade)". And it will expect to rise in northern latitude mountain systems than in mountains located in tropical and temperate zones [44].

Some of the world's most endangered and endemic species are found in mountain ecosystems [45]. Mountain ecosystems are more susceptible for small climate change. Because little change in climate can melts both the snow and ice to water. Many species can response to climate by adaptation, shifting of their geographic ranges, altering their abundance or vanishing altogether [46, 47]. Protected areas and national parks are the cornerstones of biodiversity and conservation and acting as valuable buffer against the impacts change. These areas are more vulnerable for climate change. Habitat fragmentation reduced the species movement and dispersal. Already many species are not able to survive without adequate protection of landscape [48]. Due to climate change many species of wildlife are forced to moved away from their natural habitat [49]. However if distribution of species is controlled by variations in climatic conditions or soils within certain geographic area, dispersal processes may have little consequence [50]. Sala et al. [10] carried a study about global biodiversity scenarios, they investigate that little change in precipitation or temperature in arctic, alpine, boreal forest and deserts will bring large change in biodiversity and also in species composition.

By coming 2020 major loss of biodiversity is projected in ecologically rich area of the world. While the loss of biodiversity, extinction of species already happening [51]. Wetlands are best indicators of climate change. Global warming accelerates the rate of glacial melting which directly cause flooding. Loss of wetlands is a major problem because they provide a specific life support system to unique biodiversity [52].

The mountains of Himalayas, Karakorum and Hindu Khush are more Vulnerable to Climate change $[53,54]$. A most recent study conducted by Khan et al. [53] reveals that the mountains Karakorum, Himalayas and the Hindu Khush, which are the most vital source of water for Pakistan, are more vulnerable to climate change, so that there is great need of study on the alpine ecosystems and to develop strategies and management actions for the restoration purposes. Apart from the amount of flow in the rivers the excessive melting of glaciers affects the fauna and flora of mountainous areas, the indigenous species may become extinct and exotic species may get their part in the snowless environment. Human society and the alpine ecosystems are interlinked [55]. It has been stated through many researches that, the mountain biota (tree line) is moving upward, 
due to global, climate warming, in many mountains system $[56,57,58]$.

\section{CliMATE CHANGE IN GILGIT-}

\section{BALTISTAN}

The climate of Earth is changing and the impacts are already being felt by biodiversity and wildlife habitats across the whole planet [59]. Very little research has been conducted in the Himalayan and Karakorum Highlands of northern Pakistan on the aspects of biodiversity and conservation [60]. Like other mountainous area of the world, climate changing is also taking place in Mountainous areas of Pakistan. In Gilgit-Baltistan (GB) the climate stations in Gilgit, Skardu, Gupis and Bunji shows increase in the total temperature in last two decades from 1980 to 2006, and increased by $0.440 \mathrm{C}$ per decades observed. All most all the natural ecosystems are vulnerable to climate change in GB. The rapidly melting of glaciers causes habitat loss of many species and it cause damaged in migratory routs of many migratory species [61]. GB of Pakistan has seems to be increase in precipitation and temperature has shown different trends in different seasons. There found to be more rainfall than snow [62]. Through a detailed analysis of past records of different meteorological stations of the $G B$, it was observed that, the night temperatures are increasing in the Northern Areas (GB) of Pakistan [63]. According to a research conducted by Hussain et al. [64], the maximum temperatures have increased all around the year, especially in high mountainous regions in Pakistan during the period between 1971 to 2000. Climatic conditions vary widely in the $G B$, and are characterized by low annual precipitation, a great range of mean monthly temperature values, low winter temperatures, and harsh frosts during portions of the winter season. Climate change is taking place in Gilgit-Baltistan. Information taken from different climate stations like Gilgit, Skardu, Gupis and Bunji an increase in mean temperature was observed between the years 1980 to 2006 by $0.19{ }^{\circ} \mathrm{C}$ per decade [65].

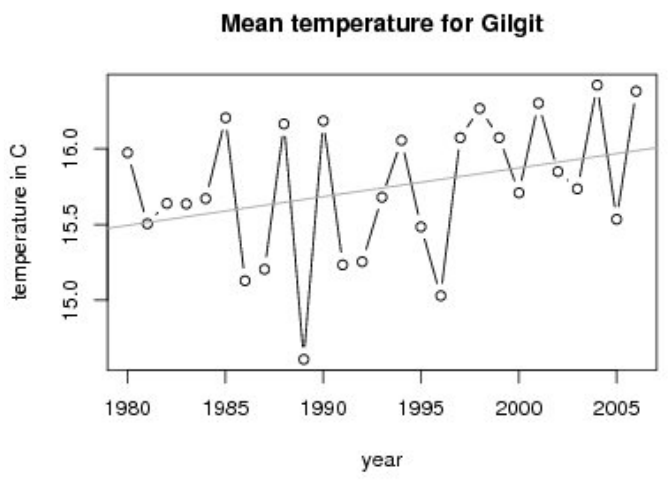

Figure 1: Mean temperature in Gilgit for 1980 to 2006. An increase by $0.19{ }^{\circ} \mathrm{C}$ per decade has been observed $(p<0.10)[65]$
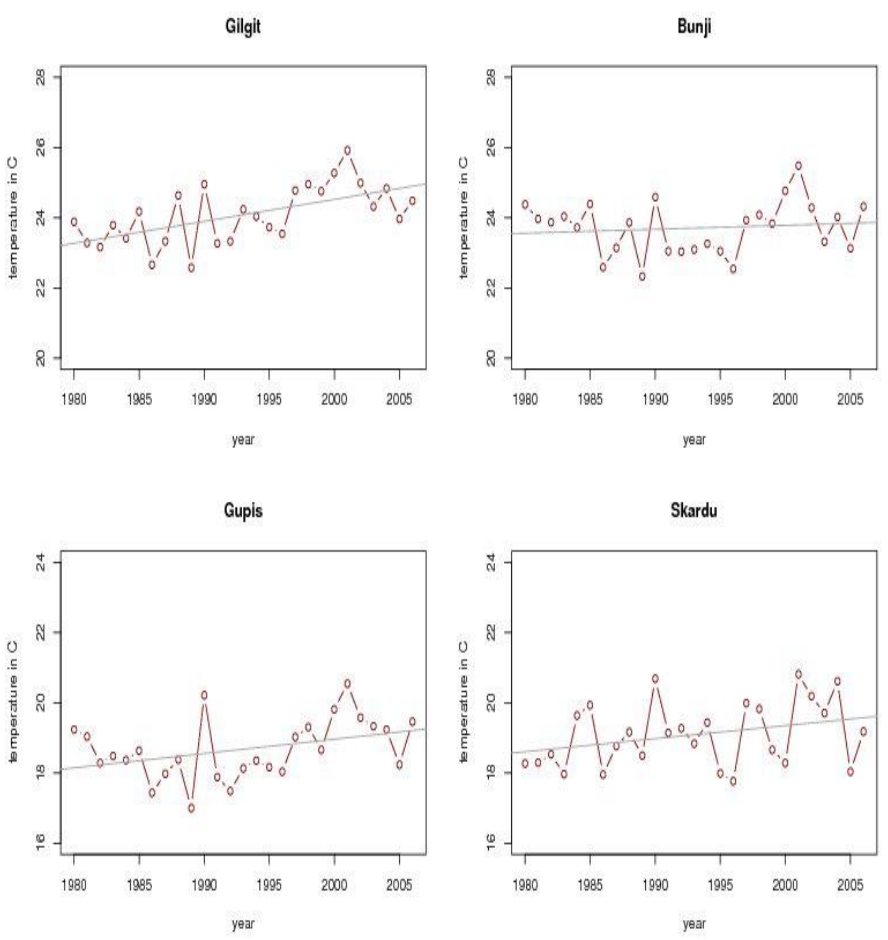

Figure 2: An increasing trend was found for maximum temperature from 1980 to 2006. Significant $(p<0.10)$ was a warming by 0.63 and $0.41^{\circ} \mathrm{C}$ decade- 
1 for Gilgit and Gupis, respectively, and $0.37{ }^{\circ} \mathrm{C}$ decade-1 for Skardu [65].

The HKH region is home to some of the world richest and varied ecosystems on the planet. These mountains are important sources of genetic diversity and resources such as timber minerals being an important source of livelihood for locals. Changes in the climatic conditions and the resulting changes in the availability of water have found adverse effect on biodiversity of these ecosystems $[64,66]$.

It was discovered that change in climate caused flash floods and river bank erosion in Skardu district GB. The flash floods emanating from glacial melting, leading to river bank which causes erosion and flooding of fields [67]. The general overview about the climate change and their associate hazards in Gilgit-Baltistan are loss of habitat, species extinction, less grasses in pasture, pest attacks, increased frequency of glacial melting, high turbid water, cold spell, GLOF, and destruction of water bank infrastructure are common ideals of the communities [68]. According to Ahmad (2010) the loss and deaths Markhor in Chitral are occurring due to disturbances and variations in the local environmental conditions, possibly triggered by climate change [69]. According to some elders in Gilgit-Baltistan a decade ago there were various birds and animal species which are now disappeared and less sited [70].

\section{FUTURE DIRECTION}

Climate change and its influence is on biodiversity is an important topic all over the world. On local scale in Gilgit-Baltistan some Non-Government Organization like Worldwide fund for nature (WWF-P), United Nation Development Program (UNDP) and
International Union for Conservation of Natural Resources (IUCN) has been trying to protect and conserve the natural resources of $G B$ and has keen interest to implement the adaptation and mitigation strategies for the Gilgit-Baltistan. It is very imperative and necessary to conserve the mountainous biodiversity, because directly or indirectly we depend on it. Gilgit-Baltistan is gifted with umber of natural resources, such as wildlife, fertile soil, glaciers, fresh water and natural forest. The climate change has got a pressure on these natural resources particular to biodiversity in Gilgit-Baltistan (GB). Understanding the impact of climate change particular to biodiversity of GB is very important for sustainable livelihood development. The mountain communities of Gilgit-Baltistan are totally dependent on natural resources. These resources are under pressure due to over exploitation. Many communities have started migration to other areas to cope from climate change. There is need of scientific research, climate modeling and ecological research to provide pertinent recommendations for climate change adaptations at community level. Ecosystem based adaptation (EBA) and Community based adaptation (CBA) is needed to focus and important for the mountain poorest communities who are badly hit by climate change and who also disproportionally reliant on the ecosystem services.

\section{KNOWLEDGE GAP IN KEY RESEARCH}

\section{AREAS}

There is knowledge gap about the climate change and its impact on different components of biodiversity, especially in reference to GilgitBaltistan. Because there is no reliable data is available about the impact of climate on 
biodiversity of GB. After literature review we have found the following knowledge gap.

1. The effect of climate change is more adverse on aquatic life (fish fauna). This component of biodiversity is still need to be debated.

2. There is need of research on climate change impact on floral species, especially the ones which are economically important for the livelihood of GB. (fruit plants, vegetation, crops)

3. The impact of climate change on migration patterns of faunal species like, migratory birds and altitudinal migration of large mammals. ( snow leopard and ungulates of $G B$ )

4. There is lack of understanding of climate change impact on high altitudes ecosystem of GB. Therefore its resources are over exploited which results in habitat loss and fragmentation, mismanagement of pastures and loss of important biodiversity.

5. The impact of climate change on range lands is still to be documented in GB.

6. The impact of climate change behavior of people of GB

\section{CONCLUSION}

An unavoidable conclusion form the above mentioned literature is that, the climate Change is not a static phenomenon, it is changing with time. The biosphere has been reacting to climate change and the effects are highly complex, in the shape of biodiversity loss. The impact of climate change is expected to increase in future. Most of the species are moving towards poles and to higher elevations [71]. Many small mammals over the world are found to be niche specialist and are more vulnerable to climate change. These small mammals are considered as indicators of climate change [72]. As GilgitBaltistan is a fragile mountainous ecosystem, little change in climate alters the ecosystem services. Human being are directly depends on biodiversity for their survival. So it is necessary that biologists should need to make better understanding of what our living world will look like in the near future [73].

People of Gilgit-Baltistan are totally dependent on natural resources, so there is great need of policy implementation for better management of natural resources and livelihood support in the changing climate. The Government organizations, NGOs and the research agencies must fill the knowledge gap, so that it will help them for policy making, which will be based on scientific findings and research base.

\section{References}

[1] G. Rasul, Climate Data and Modelling Analysis of the Indus Ecoregion. WWF - Pakistan, (2012).

[2] S. Khan, M. U. Hasan, \& M. A. Khan, People Perception about Climate Change and Adaptation in the Arid Region of Pakistan. Peshawar: Institute of Geography, Urban and Regional Planning University of Peshawar KPK, Pakistan, (2012).

[3] J. K. Rosenthal, E. D. Sclar, P. L. Kinney, K. Knowlton, R. Crauderueff, \& P. W. Brandt-Rauf, Links between the Built Environment, Climate and Population Health: Interdisciplinary Environmental Change Research in New York City. Annals Academy of Medicine , 36 (2007) 834-46.

[4] IPCC, 2001: Climate Change 2001: The Scientific Basis. Contribution of Working Group I to the Third Assessment Report of the Intergovernmental 
Panel on Climate Change [Houghton, J.T., Y. Ding, D.J. Griggs, M. Noguer, P.J. van der Linden, X. Dai, K. Maskell, and C.A. Johnson (eds.)]. Cambridge University Press, Cambridge, United Kingdom and New York, NY, USA, pp. 881.

[5] P. D. Jones, A. Moberg, Hemispheric and large-scale surface air temperature variations: An extensive revision and update to 2001 . J. Climate, 16 (2003 ) 206-223.

[6] R. K. Pachauri, Conclusion of IPCC Working Group I Fifth Assessment Report, AR4, SREX, and SRREN. Warsaw Plaond, (2013).

[7] P. Hari, M. O. Andreae, P. Kabat, \& $M$. Kulmala, A comprehensive Network of Measuring Stations to Moniter Climate change. Boreal Environment Research , (2009) 442-446.

[8] E. Nickens, C. Bowes, M. Mieja, J. Mendelson, \& M. I Murray, Air Pollution, a Warming Climate, and the Troubled Future for America's Hunting and Fishing Heritage. (2011) Retrieved 01 14, 2013, from Game Changers: http://www.nwf.org/news-andmagazines/media-

center/reports/archive/2011/gamechangers.aspx

[9] V. BROVKIN, S. SITCH, W. V. BLOH, M. CLAUSSEN, E. BAUER, W. CRAMER, Role of land cover changes for atmospheric $\mathrm{CO} 2$ increase and climate change during the last 150 years. Global Change Biology , (2004) 1253-1266.

[10] O. E. Sala, F. S. Chapin, J. J. Armesto, E. Berlow, J. Bloompeld, R. Dirzo, et al., Global Biodiversity Scenarios for the Year 2100. SCIENCE, 287 (2000) 1770-1774.

[11] Intergovernmental Panel on Climate Change (IPCC). 1995. IPCC Second Assessment Report.

[12] A. Markham, Potential impacts of climate change on ecosystems: a review of implications for policymakers and conservation biologists. Climate Research, 6 (1996) 179-191.
[13] H. F. Diaz, M. Grosjean, L. Graumlich, Climate variability and change in high elevation regions: past, present and future. Climatic Change 59 (2003) 1-4.

[14] M. Beniston, Impact of Climate Change on Mountain Region. A review of possible impacts. Climatic Change 59 (2003) 5-31.

[15] A. Guisan, A, J. Holten, R. Spichiger, and L. Tessier (eds.), 1995. Potential Ecological Impacts of Climate Change in the Alps and Fennoscandian Mountains. Publication Series of the Geneva Conservatory and Botanical Gardens, University of Geneva, Geneva, Switzerland, 194 pp.

[16] D. Nogues-Bravo, M. B. Arau’jo, M. P. Errea, J. P. Martínez-Rica, Exposure of global mountain systems to climate warming during the $21 \mathrm{st}$ Century. Science Direct, Global Environmental Change, 17 (2007) 420-428.

[17] S. Dullinger, T. Dirnböck, \& G. Grabherr, Patterns of Shrub Invasion into High Mountain Grasslands of the Northern Calcareous Alps, Austria. Arctic, Antarctic, and Alpine Research, 35 (2003) 434441.

[18] M. Beniston , H. F. Diaz, R. S. Bradley, Climatic change at high-elevation sites: an overview. Climatic Change 36 (1997) 233-252.

[19] J. Solar, Effect of Climate Change on Mountain Pine Distribution in Western Tatra Mountains, (2013) http://dx.doi.org/10.5772/54724

[20] S. G. Byars, Y. Parsons, A.A. Hoffmann, Effect of altitude on the genetic structure of an Alpine grass, Poahiemata. Annals of Botany 110 (2009) 885-99.

[21] A. A. Tahir, P. Chevallier, Y. Arnaud, L. Neppel, \& B. Ahmad, Modeling snowmeltrunoff under climate scenarios in the Hunza River basin, Karakoram Range, Northern Pakistan. Hydrology, (2011) 04-117.

[22] W. Foden, G. Mace, J. C. Vié, A. Angulo, S. Butchart, L. DeVantier, H. Dublin, A. Gutsche, S. Stuart, and E. Turak. Species susceptibility to 
climate change impacts. In: J.-C. Vié, C. HiltonTaylor and S.N. Stuart (eds). The 2008 Review of The IUCN Red List of Threatened Species (2008). IUCN Gland, Switzerland.

[23] A. Campbell, V. Kapos, J. P. Scharlemann, P. Bubb, A. Chenery, L. Coad, et al., REVIEWOF THE LITERATURE ON THE LINKS BETWEEN BIODIVERSITY AND CLIMATE CHANGE; Impacts, Adaptation and Mitigation. Montreal, Quebec, Canada: Secretariat of the Convention on Biological Diversity. (2009).

[24] A. Shah, Climate change affects Biodiversity. Global Issues (2012).

http://www.globalissues.org/article/172/climate change-affects-biodiversity

[25] M. M. lqbal, \& A. M. Khan, CLIMATE CHANGE THREATS TO BIODIVERSITY IN PAKISTAN. Islamabad: World Environment Day, (2010).

[26] J.A. Khan, CHANGING CLIMATIC PATTERNS AND THEIR IMPACTS WITH SPECIAL FOCUS ON PAKISTAN, (2010).

[27] R. Slatyer, Climate change impacts on Australia's alpine ecosystems. The ANU Undergraduate Research Journal 2 (2010).

[28] H. F. Diaz, \& R. S. Bradley, Temperature variations during the last century at High elevation sites. Climatic Change, 36, (1997) 253-279.

[29] K. Hennessy, P. Whetton, L. Smith, J. Bathols, M. Hutchinson, \& J. Sharples, The impact of climate change on snow conditions in mainland Australia. CSIRO Atmospheric Research, Aspendale, (2003).

[30] G. R. Walther, S. Beissner\& C. A. Burga, Trends in the upward shift of alpine plants. Journal of Vegetation Science 16, (2005) 541-8.

[31] M. Beniston, W. Haeberli, SENSITITVITY OF MOUNTAIN REGIONS TO CLIMATIC CHANGE. GEO Publications, Hamburg, (2001) 237-244.

[32] Q.-U. Z. Chaudhry, A. Mahmood, G. Rasul, \& M. Afzaal, Climate Change Indicators of Pakistan . PAkistan Meterological Department (2009).
[33] M. Zahida, \& G. Rasula, FREQUENCY OF EXTREME TEMPERATURE \& PRECIPITATION EVENTS IN PAKISTAN 1965-2009. Sci.Int. (Lahore), (2011) 313-319.

[34] A. A. Chaudhry, Forest and climate Change. World Environmental Day, June 2011.

[35] M. A. Munoz, A. Faz, A. R. Memut, Soil Carbon Reservoirs at High-Altitude Ecosystems in the Andean Plateau. Climate Change Impacts on High-Altitude Ecosystems, Springer International Publishing, (2015) 135-153.

[36] N. Nikolaishvili, L. Matchanariani, Impacts of Climate Change on Georgia's Mountain Ecosystems. Climate Change Impacts on HighAltitude Ecosystems. Springer International Publishing, (2015) 245-274.

[37] G. Parolly, The High-Mountain Flora and Vegetation of the Western and Central Taurus Mts. (Turkey) in the Times of Climate Change. Climate Change Impacts on High-Altitude Ecosystems. Springer International Publishing, (2015) 9-133.

[38] Convention on the Conservation of European Wildlife and Natural Habitats. Impact of Climate Change on Mountain Biodiversity in Eurpoe. (2010).

[39] E. M. Spehn, K. Rudmann-Maurer, C. Körner, D. Maselli (eds.), Mountain Biodiversity and Global Change. GMBA-DIVERSITAS, Basel, (2010)

[40] T. Kohler and D, Maselli (eds). Mountains and Climate Change - From Understanding to Action. Published by GeographicaBernensia with the support of the Swiss Agency for Development and Cooperation (SDC), and an international team of contributors. Bern. (2009).

[41] International Centre for Integrated Mountain Development. (2009). Mountain Biodiversity and Climate Change. Kathmandu, Nepal: ICIMOD.

[42] N. Chettri, B. Shakya, \& E. Sharma, Biodiversity Conservation in the Kangchenjunga Landscape. Kathmandu, Nepal: International Centre for 
Integrated Mountain Development (ICMOD), (2008).

[43] USAID. 2001. CHANGING GLACIERS AND HYDROLOGY IN ASIA ADDRESSING VULNERABILITIES TO GLACIER MELT IMPACTS. USAID Environmental Health IQC (EHIQC, Contract GHA-I-00-04-00006/Task Order \# 2, Line Item \# 2), managed by CDM International Inc.

[44] N. D. Bravo, M. B. Araujo, M. P. Errea, \& J. P. Martınez-Rica, Exposure of global mountain systems to climate warming during the 21st Century. Global Environmental Change , (2007) 420-428.

[45] S.K. Behera, Impact of Climate Change on Mountains Ecosystems of India: Special Reference to the Himalayas. International Society of Environmental Botanist, Enviro News, 18 (2012).

[46] K. Tse-ring, E. Sharma, N. Chettri, \& A. Shrestha, Climate Change Impact and Vulnerability in the Eastern Himalayas - Synthesis Report. Kathmandu, Nepal: International Centre for Integrated Mountain Development ( ICMOD), (2010)

[47] M. A. Nawaz, P. Shadie, V. Zalaria, Central Karakorum Conservation Complex, Draft Management Plan (IUCN). GilgitBaltistan (2009).

[48] K. MacKinnon, C. Sobrevila, \& V. Hickey, Biodiversity, Climate Change and Adaptation; Nature-Based Solutions from the World Bank Portfolio. Washington: The International Bank for Reconstruction and Development / THE WORLD BANK (2008).

[49] B. Walsh, How Climate Change Will Impact Animals. Retrieved jan 9, 2013, from Time Sciences and space: (2008) http://www.time.com/time/health/article/0,8599 ,1849698,00.htmlConvention on the Conservation of European Wildlife and Natural Habitats. Impact of Climate Change on Mountain Biodiversity in Eurpoe, (2010).
[50] G. P. Juli \& P. A. Mike, Patterns of plant species richness in relation to different environments: An appraisal. Vegetation Science, (2001)153-166.

[51] D. Leary, B. Pisupati, (eds). 2010. The Future International Environmental Law. United Nation University Press.

[52] M. Malik, A. Imran, N. Naseer, R. Mahmood, \& et, al., Wetlands as Indicators of Climate Change. Nature, A quarterly magazine of WWF-Pakistan, 34 (2010) 1-32

[53] M. A. Khan, B. Gul, H. Khan, Impact of Climatic Change on Flora of High Altitudes in Pakistan. Springer International Publishing. (2015) 361-381.

[54] J. Y. Gerlitz, S. Banerjee, N. Brooks, M. Macchi, An Approach to Measure Vulnerability and Adaptation to Climate Change in the Hindu Kush Himalayas. Handbook of Climate Change Adaptation. Springer Berlin Heidelberg. (2014) 122.

[55] P.W. Bierman-Lytle, Climate Change Impact on High-Altitude Ecosystems and Their Impact on Human Communities. Climate Change Impacts on High-Altitude Ecosystems. Springer International Publishing, (2015) 289-341.

[56] G. Grabherr, M. Gottfried, H. Pauli, Climate effects on mountain plants. Nature, 369 (1994) 448.

[57] H. Pauli, M. Gottfried, K. Reiter, C. Klettner, G. Grabherr, Signals of range expansions and contractions of vascular plants in the high Alps: observations (1994-2004) at the GLORIA master site Schrankogel, Tyrol, Austria. Glob Change Biol 13 (2007) 147-156.

[58] A. El-Keblawy, Impact of Climate Change on Biodiversity Loss and Extinction of Endemic plants of Arid Land Mountains. J Biodivers Endanger Species 1 (2014) 2-20.

[59] R. E. Green, M. Harley, L. Miles, J. Scharlemann, A. Watkinson, \& O. Watts, Global Climate Change and Biodiversity. East Anglia, Norwich, UK: University of East Anglia, Norwich, UK, (2003). 
[60] K. Sheikh, T. Ahmad, M. A. Khan, Use, exploitation and prospects for conservation: people and plant biodiversity of Naltar Valley, northwestern Karakorums, Pakistan. Biodiversity and Conservation, 28 (2002) 715-742.

[61] B. Khan, F. Ali, Understanding sectorial impacts of climate change on Gilgit-Baltistan. Regional climate risk reduction project ( RCRRP); . (2011), UNDP-ECHO initiative.

[62] International Centre for Integrated Mountain Development. (2010). Climate change impacts on the water resources of the Indus Basin. Kathmandu, Nepal: ICIMOD.

[63] S. B. Cheema, G. Rasul, \& D. H. Kazmi, Evaluation of Projected Minimum Temperatures for Northern Pakistan. Pakistan Journal of Meteorology, (2011) 63-70.

[64] S. S. Husnain, M. Mudasser, M. M. Sheikh, N. Manzoor, Climate Change and Variability in [64] Mountain Regions of Pakistan Implication for Water and Agriculture. Pakistan Journal of Meteorology, 2 (2005) 75-90.

[65] M. J. Steinbaver, \& J. Zeidler, Climate Change in the Northern Areas Pakistan Impacts on glaciers, ecology and livelyhoods. Gilgit: World Wide Fund for Nature-Pakistan Gilgit Conservation and Information Center (GCIC) NLI Colony, Jutial Gilgit, (2008).

[66] S. P. Singh, I. B. Khadka, B. S. Karky, \& E. Sharma, Climate Change in the Hindu KushHimalayas; The State of Current Knowledge. Kathmandu, Nepal,: International Centre for Integrated Mountain Development (ICMOD), (2011).
[67] World Wide Fund. 2012. Facing the Future with Confidence Shigar Community Adapts to Changing Environment and Economics. WWF-P

[68] F. Ali, (2010, Dec 2). CLIMATE CHANGE PROBABILITY IN GILGIT-BALTISTAN. Retrieved Feb 1. 2013, from Pamir Times: http://pamirtimes.wordpress.com/tag/climatechange/

[69] K. Ahmad, (2010, April 14). Wildlife official sees climate change behind the death of 7 Markhors in Chitral. Retrieved feb 1, 2013, from Pamir Times: http://pamirtimes.wordpress.com/201 1/04/14/wil dlife-official-sees-climate-change-behind-thedeath-of-7-markhors-in-chitral/

[70] S. Ishaq, People Perception of climate Change Impact on Mountain Biodiversity in GilgitBaltitsan, (2013), GClC-GB WWF-Gilgit (Unpublished report)

[71] A. M. FRANCO, J. K. HILL, C. KITSCHKE, Y. C. COLLINGHAM, D. B. ROY, R. FOX, et al. Impacts of climate warming and habitat loss on extinctions at species' low-latitude range boundaries. Global Change Biology, (2006) 15451553.

[72] H. B. Katuwal, and S. Koirala (Eds.), Proceedings of Third Seminar on Small Mammals Issues. Small Mammals Conservation and Research Foundation, New Baneshwor, Kathmandu, Nepal, (2012) 55.

[73] F. Krupp, L. J. Musselman, M. A. Kotb, I. Weidig, The effects of Climate change on biodiversity: Pressing issues and research priorities. BioRisk, 3 (2009) 1-4. 